\title{
A follow up study of cytomegalovirus infection in a group of Turkish renal transplant recipients using molecular assays
}

\author{
Meltem Yalinay Cirak/ ${ }^{+}$, Seyyal Rota, Isil Maral*, Sevgi Turet, Sukru Sindel** \\ Department of Medical Microbiology *Department of Public Health **Department of Nephrology, Faculty of Medicine, \\ Gazi University, Besevler, Ankara, Turkey
}

\begin{abstract}
The clinical value of an in-house cytomegalovirus nested polymerase chain reaction (CMV-PCR) and a commercial molecular assay hybrid capture CMV DNA assay (HCA) was evaluated in monitoring a group of renal transplant patients for six months follow up. In this study, the sensitivity, specificity, positive predictive value, and negative predictive value of nested CMV DNA PCR assay and HCA at the beginning of the study were 70, 42.9, 46.7, 66.7, and 60, 78.6, 66.7, and 73.3\% respectively. After six months, they were 80, 66.7, 80, 66.7 for CMV PCR and 73.3, 88.9, 91.7, 66.7\% for HCA respectively. These results indicate that in monitoring and predicting CMV infections in renal transplant recipients, not only qualitative but also quantitative assays must be used together in order to decide the preemptive strategies.
\end{abstract}

Key words: cytomegalovirus - polymerase chain reaction - hybridization

Human cytomegalovirus (CMV) infection is responsible for significant mortality and morbidity and graft failure in renal transplant recipients (Tong et al. 1998). The early identification of CMV is important as the majority of patients develop infection and the best result is obtained when treatment is started earlier (Rubin \& Tolkoff-Rubin 1993). CMV must be detected before clinical symptom appearance, but virus detection is not always followed by CMV disease (Eckart et al. 1997). Laboratory diagnosis of CMV infection is based primarily on the detection of CMV viremia and active CMV infection after the onset of symptoms. By means of advanced laboratory assays, it is possible to have positive laboratory assay results before the onset of symptoms. However, laboratory diagnosis of active CMV infection is not always associated with symptomatic disease (Tong et al. 1998) and the identification of these patients for clinically relevant disease is difficult.

Various qualitative and quantitative molecular assays are used to monitor renal transplant recipients and they appear to be more convenient and sensitive than the traditional methods such as serology, virus cultures and shell vial assays. The detection CMV DNA in leukocytes or plasma by polymerase chain reaction (PCR) is the most sensitive method of identifying CMV disease. However a highly sensitive CMV-PCR may detect latent virus that is not involved in disease (Rollag et al. 1998). The commonly used DNA hybridization assays offer the advantage of objective CMV DNA detection and quantification without the hazards of PCR such as contamination or inhibition (Aitken et al. 1999).

Financial support: Gazi University, Project 01/99-19 +Corresponding author. E-mail: meltemyc@ gazi.edu.tr Received 6 December 2004

Accepted 28 March 2005
The aim of this study was to monitor a group of adult Turkish renal transplant patients for six months follow up by using PCR and hybrid capture CMV DNA assay (HCA) in detecting and predicting CMV disease and to evaluate the relationship between the CMV-DNA presence and the symptomatic human CMV infection. As far as we are concerned this is the first follow up study in renal transplant patients using molecular assays in Turkey.

\section{MATERIALSAND METHODS}

Patients and specimens - Blood samples were obtained from 24 kidney transplant recipients who were CMV IgG positive. EDTA-anticoagulated blood samples were collected at monthly intervals during six months. All of the blood samples were evaluated with both PCR and HCA at the beginning of this follow up study and after six months. In the same way, the clinical symptoms of the patients were evaluated at the beginning of this follow up study and after six months. In addition, blood samples from 20 healthy individuals (with no recent CMV infection but seven of whom were CMV seropositive) were also tested as controls. Confirmation of CMV disease was based on the clinical signs and symptoms, history and response to antiviral therapy.

Definitions - The diagnosis of CMV disease was based on the criteria defined at the International CMV Workshop (Ljungman \& Plotkin 1995), in which the detection of CMV viremia is associated with one or more of the following symptoms and signs: (i) pyrexia with or without general malasie and with or without leukopenia (defined as fever of $\geq 38^{\circ} \mathrm{C}$ for $\geq 48 \mathrm{~h}$ in the absence of transplant rejection or intercurrent infection); (ii) pneumonitis (defined as symptoms of hypoxia with or without interstitial changes on chest $\mathrm{X}$ ray and the detection of CMV in bronchoalveolar lavage fluid), and (iii) hepatitis (defined as a alanine aminotransferase level twice the upper limit of normal).

Nested PCR - DNA for CMV-PCR was extracted from total leukocytes by using Heliosis ${ }^{\circledR}$ DNA extraction kit 
(Metis Biotechnology Ltd., Ankara, Turkey) according to manufacturers' instructions. In-house nested PCR procedure was performed for the amplification of last $225 \mathrm{bp} \mathrm{3}$ end of 20UL97 open reading frame (Chee et al. 1989). The outer primer set consists of ULS1 (position 1309-1330) and ULA2 (position 1705-1685) primers (Chatellard et al. 1998). The second round of amplification was performed by using sense 5'-CACCAGTGTCGTGTATGCCA-3' (position 1342-1361) and antisense 5'-AAGCAGGGTGG TAACATTCG-3' (position 1567-1546) inner primer set. The outer set of primers used in the first round PCR reaction amplified a 386-bp fragment of the UL97 open reading frame, while the inner set, used in the nested reaction, amplified a 225-bp of the UL97. Details of the first round PCR (Chatellard et al. 1998) and the second round PCR (Bale et al. 1993) have been described previously. The amplification products were analyzed by agarose gel electrophoresis and ethidium bromide staining. The analytical sensitivity of the PCR protocol was found to be between 1000-1250 CMV copies/ml blood. The detection limit was determined by performing the entire CMV PCR procedure on serial dilutions of a known amount of CMV AD169 DNA in a CMV PCR negative blood.

$H C A$ - The amount of CMV-DNA in leukocytes was quantified with the Hybrid Capture Assay (HCA) (Digene Hybrid Capture Assay, version 2.0, US). The HCA is a solution hybridization antibody capture assay: the target DNA hybridizes with a specific CMV-RNA probe coctail (complementary to $17 \%$ of viral genome) and the resultant hybrids are captured with specific anti-RNA-DNA antibodies. Immobilized hybrids are then reacted with an alkaline phosphatase conjugate and detected with a chemiluminiscent substrate. The detection limit was estimated at $8 \mathrm{pg} / \mathrm{ml}$ of tested specimen, corresponding to $2 \times$ $10^{4}$ genomes/assay.

Statistical analysis - Sensitivity, specificity, positive predictive value and negative predictive value were calculated at the beginning of this follow up study and after six months. The Mann-Whitney rank sum test for equality of medians was used to compare the amounts of CMVDNA in symtomatic and asymptomatic infections. $\mathrm{P}<0.05$ was considered significant for statistical analysis.

\section{RESULTS}

Twenty four kidney transplant recipients were monitored for CMV infection in blood and for the symptoms of CMV disease. Ten of the patients were symptomatic whereas 14 were asymptomatic at the beginning of the study. CMV activation was defined as any evidence of virus replication, i.e. a positive nested PCR or a positive HCA on leukocytes. There was no evidence of such activation by both of these methods in samples from healthy controls.

After six months, the clinical pattern of some of these patients changed and 5 of the 14 asymptomatic patients became clinically symptomatic. Hence there were $15 \mathrm{symp}-$ tomatic and 9 asymtomatic patients after six months. These five patients have had already positive PCR results prior to symptoms and all of the three asymptomatic patients with positive HCA results developed symptoms.

The results of nested PCR and HCA to detect CMVDNA in at the beginning of the study are shown in Table I. Sensitivity, specificity, positive predictive value and negative predictive value for the detection of CMV in blood are described in Table II. As shown in these tables the methods differ in their sensitivity, specificity, positive predictive value and negative predictive. The problem associated with the use of very sensitive qualitative PCR assay leads to a particularly low positive predictive value.

After six months the comparison of the results from PCR and HCA tests according to the patients symptoms shows that all 5 patients out of 8 asymptomatic ones with positive PCR results and all of the 3 patients prior to onset of symptoms with positive HCA results have become clinically symptomatic. The validity values of these patients according to their symptomatic change were shown in Table III.

\section{TABLE I}

The results of a nested polymerase chain reaction (PCR) and a hybrid capture assay (HCA) to detect cytomegalovirus (CMV)-DNA in leukocytes

\begin{tabular}{lccccr}
\hline CMV infection & \multicolumn{2}{c}{$\begin{array}{c}\text { No. of patients } \\
\text { with positive results }\end{array}$} & $\begin{array}{c}\text { No. patients with positive results } \\
\text { prior to or at onset of symptoms }\end{array}$ & $\begin{array}{c}\text { Median amount of } \\
\text { CMV detected (range) }\end{array}$ \\
\hline PCR & HCA & PCR & HCA & HCA $^{a}$ \\
Symptomatic (14) & 8 & 3 & 5 & 3 & $0.0(0-44.8)$ \\
\hline
\end{tabular}

$a: \mathrm{pg} / \mathrm{ml}$ blood; $b$ : $\mathrm{P}<0.05$ vs HCA in asymptomatic patients.

\section{TABLE II}

Sensitivity, specificity, positive predictive value and negative predictive value of cytomegalovirus (CMV)-polymerase chain reaction (PCR) and hybrid capture assay (HCA) for the detection of CMV in blood at the beginning of the study

\begin{tabular}{lcccc}
\hline Test & $\begin{array}{c}\text { Sensitivity } \\
\text { (test +/disease +) }\end{array}$ & $\begin{array}{c}\text { Specificity } \\
\text { (test -/disease -) }\end{array}$ & $\begin{array}{c}\text { PPV } \\
\text { (disease +/test +) }\end{array}$ & $\begin{array}{c}\text { NPV } \\
(\text { disease }-/ \text { test -) }\end{array}$ \\
\hline CMV-PCR & $7 / 10(70 \%)$ & $6 / 14(42.9 \%)$ & $8 / 15(46.7 \%)$ & $6 / 9$ \\
HCA & $6 / 10(60 \%)$ & $11 / 14(78.6 \%)$ & $6 / 9(66.7 \%)$ & $11 / 15(73.3 \%)$ \\
\hline
\end{tabular}


TABLE III

Sensitivity, specificity positive predictive value and negative predictive value of cytomegalovirus (CMV)- polymerase chain reaction (PCR) and hybrid capture assay (HCA) for the detection of CMV in blood after one year

\begin{tabular}{lcccc}
\hline Test & $\begin{array}{c}\text { Sensitivity } \\
\text { (test +/disease +) }\end{array}$ & $\begin{array}{c}\text { Specificity } \\
\text { (test -/disease -) }\end{array}$ & $\begin{array}{c}\text { PPV } \\
\text { (disease +/test +) }\end{array}$ & $\begin{array}{c}\text { NPV } \\
(\text { disease -/test -) }\end{array}$ \\
\hline CMV-PCR & $12 / 15(80.0 \%)$ & $6 / 9(66.7 \%)$ & $12 / 15(80.0 \%)$ & $6 / 9(66.7 \%)$ \\
HCA & $11 / 15(73.3 \%)$ & $8 / 9(88.9 \%)$ & $11 / 12(91.7 \%)$ & $8 / 12(66.7 \%)$ \\
\hline
\end{tabular}

\section{DISCUSSION}

CMV is an important pathogen after renal transplantation. Early identification of viremia followed by preemptive therapy should reduce the number of patients developing significant disease. Laboratory tests are generally used for the diagnosis of active CMV infection after the onset of symptoms. By means of more sensitive assays it is possible to have positive laboratory assay results before the onset of disease. However, laboratory diagnosis of active CMV infection is not always associated to symptomatic CMV disease.

CMV as a member of Herpesviridae, establishes latency upon primary infection which occurs early in life in a majority of individuals (Britt \& Alford 1996). The term latency refers to the presence of viral genome in the absence of active production of infectious virus. As a matter of fact, in CMV seropositive immunocomprised hosts the nature of infection can be summarized in three steps: latent infection, reactivation of infection without symptoms and symptomatic infection (Chatellard et al. 1998). For practical purposes, the diagnostic assays establish whether the infection is active and the reactivation of infection can be easily diagnosed by the detection of infectious virus or nucleic acids in patients' samples.

In transplant recipients CMV can be detected in the blood days or even weeks before the onset of clinical symptoms. A positive CMV test days or weeks before the onset of symptoms is of clinical value as a majority of patients will develop disease and preemptive antiviral therapy is considered.

In recent years molecular methods are considered as gold standart as they are more sensitive than the conventional methods such as virus culture, shell vial assay, serology and antigen detection. Molecular methods enable detection of virus prior to onset of symptoms (Kulkarini et al. 2001). The PCR assay is developed for more practical and sensitive application to diagnosis of CMV infection. In addition to its diagnostic potential, detection of CMV infection by PCR occurs at very early times compared with conventional detection (Einsele et al. 1991). On the other hand, Rollag et al. indicates that HCA assay for quantitative assessment of CMV-DNA in leukocytes can be very useful in the surveillance of CMV infection and disease (1998). Furthermore Weinberg et al. (2002) reports that the molecular detection of CMV-DNA by HCA is more sensitive when whole blood or leukocytes is used than when plasma is used. Another study shows that HCA is an efficient assay for detecting and quantifying CMV viremia, for the test format is standardized and not subject to contamination or inhibition (Barrett-Muir et al. 1998).
In this work we prospectively studied the utility of PCR and HCA for diagnosis of human CMV infection and emphasized the predictive value of the molecular methods in CMV activation in an immunosupressed group, renal transplant patients. The sensitivity, specificity, positive predictive value, and negative predictive value of nested CMV DNA PCR assay and HCA at the beginning of the study were $70,42.9,46.7,66.7$ and $60,78.6,66.7$, and $73.3 \%$ respectively. After six months, they were $80,66.7$, 80, 66.7\% for CMV PCR and 73.3, 88.9, 91.7, 66.7\% for HCA respectively. In terms of specificity and PPV, the HCA appears superior. However in the case of sensitivity PCR seems to be more superior. These results raise the question of whether the PCR assay will be too sensitive to distinguish among the population of CMV-seropositive transplant recipients, the subgroup at high risk for progressive infection. In particular increasing the sensitivity is important inspite of the few reported false-negative results (Cantanzarit et al. 1993, Donner et al. 1993, Nicolini et al. 1994, Mulango et al. 1995, Revello et al. 1995), but the lower sensitivity might be problematic with respect to early detection of CMV relapse or therapy monitoring (Gerna et al. 1994).

The sensitivity of the leukocyte assays in this study is consistent with previous findings reported in Tong et al. (1998), Eckart et al. (1997), Rollag et al. (1998), Schäfer et al. (1998). CMV DNA in leukocytes may appear earlier and persist longer than CMV DNA in plasma. Studies concerning the sensitivity of leukocyte PCRs demonstrate their convenience as they are positive 8 to 13 days before the onset of illness on average (Tong et al. 1998, 2000). According to Eckart et al. (1997) DNA in leukocytes is the earliest diagnostic method and appears 22 days before clinical symptoms. Moreover the detection of CMV DNA in polymorphonuclear leukocytes is associated with active infections and is more sensitive than detection of CMV DNA in plasma as shown in a study by Schäfer et al. (1998). Although infectious CMV has occasionally been recovered from plasma (Gerna et al. 1994, Spector et al. 1992), shedding of CMV DNA from lysed leukocytes into the plasma is a possible explanation in the sensitivity difference of leukocytes and plasma (Zipeto et al. 1995). Considering all of these, leukocyte assays seem to be more convenient in follow-up studies.

The differences in the positive predictive value of PCR and $\mathrm{HCA}$ at the beginning (46.7 and $66.7 \%$, respectively) and end of the study (80 and $91.7 \%$, respectively) indicate the reliability of both assays for monitoring and predicting the active CMV infection.

In conclusion, we have been able to demonstrate the 
clinical utility of both PCR and HCA for monitoring CMV infections in renal transplant recipients. PCR is more sensitive and HCA is more specific for monitoring these patients. The usage of both assays, qualitative PCR and quantitation of viral DNA together; seems to be more efficient for careful monitoring of CMV infections and for deciding antiviral treatment strategies in renal transplant patients. The positive results of asymptomatic patients must be taken into consideration as they may later develop disease and early antiviral therapy will be more efficient for the clinical outcome. The cost of these methods in this diagnostic strategy can be undervalued when compared with the benefit of the most correct diagnosis of the infection.

New assays based on molecular techniques have become available for routine CMV diagnosis (HalwachsBaumann et al. 2001) and a lot of another based on different strategies have been developed recently (Hong et al. 2004, Foldes-Papp et al. 2004). The critical point is the determination of clinically relevant CMV activation from latency and the earliest time for accurate detection of this activation.

\section{REFERENCES}

Aitken C, Barrett-Muir W, Millar C, Templeton K, Thomas J, Sheridan F, Jeffries D, Yaqoob M, Breuer J 1999. Use of molecular assays in diagnosis and monitoring of cytomegalovirus disease following renal transplantation. J Clin Microbiol 37: 2804-2807.

Bale Jr JF, O’Neil ME, Fowler SS, Murphy JR 1993. Analysis of acquired human cytomegalovirus infections by polymerase chain reaction. J Clin Microbiol 31: 2433-2438.

Barrett-Muir WY, Aitken C, Barrett-Muir W, Templeton K, Raftery M, Kelsey SM, Breuer J 1998. Evaluation of the digene hybrid capture cytomegalovirus DNA assay versus plasma PCR and shell vial assay for diagnosis of human cytomegalovirus viremia in immunocompromised patients. J Clin Microbiol 36: 2554-2556.

Britt WJ, Alford CA 1996. Cytomegalovirus. In BN Fields, DM Knipe, PM Howley (eds), Fields Virology, Lippincott Raven, Philadelphia, p. 2493-2532.

Cantanzarite V, Danker WM 1993. Prenatal diagnosis of congenital cytomegalovirus infection: False negative amniocentesis at 20 weeks' gestation. Prenatal Diag 13: 1021-1025.

Chatellard P, Sahli R, Iten A, Von Overbeck J, Meylan PRA 1998. Single tube competitive PCR for quantitation of $C M V$ DNA in the blood of HIV+ and solid organ transplant patients. J Virol Methods 71: 137-146.

Chee MS, Lawrence GL, Barell BG 1989. Alpha-, beta- and gamma-herpes viruses encode a putative phosphotransferase. J Gen Virol 70: 1151-1160.

Donner C, Liesnard C, Content J, Busine A, Aderca J, Rodesch F 1993. Prenatal diagnosis of 52 pregnancies at risk for congenital cytomegalovirus infection. Obstet Gynecol 82: 481-486.

Eckart P, Brouard J, Vabret A, Freymuth F, Guillot M, Ryckelynck JP, De Ligny B 1997. Detection of human cytomegalovirus in renal transplantation: comparison of four diagnostic methods: DNA in sera by polymerase chain reaction (PCR), DNA in leukocyte by PCR, pp65 leukocytic antigenemia, and viremia. Transplantation Proc 29: 23872389.

Einsele H, Steidle M, Vallbracht A, Saal JG, Ehninger G, Muller CA 1991. Early occurrence of human cytomegalovirus infection after bone marrow transplantation as demonstrated by polymerase chain reaction technique. Blood 77: 11041110.

Foldes-Papp Z, Egerer R, Birch-Hirschfeld E, Striebel HM, Demel U, Tilz GP, Wutzler P 2004. Detection of multiple human herpes viruses by DNA microarray technology. Mol Diagn 8:1-9.

Gerna G, Furione M, Baldanti F, Sarasini A 1994. Comparative quantitation of human cytomegalovirus DNA in blood leukocytes and plasma of transplant and AIDS patients. J Clin Microbiol 32: 2709-2717.

Halwachs-Baumann G, Wilders-Trusching M, Enzinger G, Eibl M, Linkesch W, Dornbusch H J, Santner BI, Marth E, Kessler HH 2001. Cytomegalovirus diagnosis in renal and bone marrow transplant recipients: the impact of molecular assays. J Clin Virol 20: 49-57.

Hong KM, Najjar H, Hawley M, Press RD 2004. Quantitative real-time PCR with automated sample preparation for diagnosis and monitoring of cytomegalovirus infection in bone marrow transplant patients. Clin Chem 50: 846-856.

Kulkarini A, Westmoreland D, Fox JD 2001. Molecular-based strategies for assessment of CMV infection and disease in immunosupressed transplant recipients. Clin Microbiol Infect 7: 179-186.

Ljungman P, Plotkin S 1995. Workshop on CMV disease-definitions, clinical severity scores and new syndromes. Scand J Infect Dis (Suppl.) 99: 87-89.

Mulango KN, Lamy ME, Van Lierde M 1995. Requirements for diagnosis of prenatal cytomegalovirus infection by amniotic fluid culture. Clin Diag Virol 4: 231-238.

Nicolini U, Kustermann A, Tassis B, Fogliani R, Galimberti A, Percivalle E, Revello MG, Gerna G 1994. Prenatal diagnosis of congenital human cytomegalovirus infection. Prenatal Diag 14: 903-906.

Revello MG, Baldanti F, Furione M, Sarasini A, Percivalle E, Zavattoni M, Gerna G 1995. Polymerase chain reaction for prenatal diagnosis of congenital human cytomegalovirus infection. J Med Virol 47: 462-466.

Rollag H, Sagedal S, Holter E, Degré M, Ariansen S, Nordal KP 1998. Diagnosis of cytomegalovirus infection in kidney transplant recipients by a quantitative RNA-DNA hybrid capture assay for cytomegalovirus DNA in leukocytes. Eur J Clin Microbiol Infect Dis 17: 124-127.

Rubin RH, Tolkoff-Rubin NE 1993. Antimicrobial strategies in the care of organ transplant recipients. Antimicrob Agents and Chemother 37: 619-624.

Schäfer P, Tenschert W, Cremaschi L, Gutensohn K, Laufs R 1998. Utility of major leukocyte subpopulations for monitoring secondary cytomegalovirus infections in renal-allograft recipients by PCR. J Clin Microbiol 36: 1008-1014.

Spector SA, Merill R, Wolf D, Danker WM 1992. Detection of human cytomegalovirus in plasma of AIDS patients during acute visceral disease by DNA amplification. J Clin Microbiol 30: 2359-2365. 
Tong CYW, Cuevas L, Williams H, Bakran A 1998. Use of laboratory assays to predict cytomegalovirus disease in renal transplant recipients. J Clin Microbiol 36: 2681-2685.

Tong CYW, Cuevas L, Williams H, Bakran A 2000. Prediction and diagnosis of cytomegalovirus disease in renal transplant recipients using qualitative quantitative polymerase chain reaction. Transplantation 15: 985-991.
Weinberg A, Schissel D, Giller R 2002. Molecular methods for cytomegalovirus surveillance in bone marrow transplant recipients. J Clin Microbiol 40: 4203-4206.

Zipeto D, Morris S, Hong A, Dowling A, Wolitz R, Merigan TC, Rasmussen L 1995. Human cytomegalovirus (CMV) DNA in plasma reflects quantity of CMV DNA present in leukocytes. J Clin Microbiol 33: 2607-2611. 
